\title{
The Cuban revolution of 1959 - legitimating an ongoing revolutionary process
}

\author{
Nina JANY ${ }^{1}$
}

University of Fribourg

\section{Introduction}

On 1 January 2018, the Republic of Cuba officially celebrated the 59th anniversary of the triumph of the revolution - an expression commonly used to describe the takeover of the rebels under the leadership of Fidel Castro in 1959 - and entered year sixty of the revolution. The "remarkable endurance of the Cuban revolution" (Kapcia 2008: 7), or at least the perception and representation of an enduring revolution, is certainly one of its peculiarities. Indeed, within the Cuban context, the term revolution is often used to describe an "ongoing state political project - event, structure, and process" (Gropas 2007: 533). A project which is, up until today, under construction. Conceptually speaking, one may question whether it is even possible that a revolution may last for more than five decades. Actually, no overall definition of revolution exists. The term is contested, and claimed by different strands and movements (Grosser 2013: 22). Since revolution can be considered as a category of self-interpretation of those who are involved in it (Endruweit, Trommsdorff and Burzan 2014: 408), and since incompleteness and open-endedness are inherent to the concepts of revolution and revolutionary change (Grosser 2013: 21; Scott and Marshall 2014: 633), conceptual arguments for the perception of an ongoing Cuban revolution can be provided.

When engaging with the idea of an ongoing revolutionary process, one can ask how this ongoing process of the Cuban revolution has been constructed and justified over time. While "the weight and oppressiveness of the Cuban state" (Farber 2011: 37), the repression and the eliminating of opponents and dissidents have played an important role, there has always been popular support for the revolution - or at least for parts of it. Where did and does this support come from - in other words, what has given legitimacy to the lasting project of the Cuban revolution? In the following, some elements of the historiography of the Cuban revolution of 1959 and its emphasis on so-called revolutionary moral and values will be presented as two important legitimating components of this revolution. To do so, we will, in a first step, give a brief overview of the historical context of the Cuban island before 1959. In a second step, the triumph of the revolution and the building of a revolutionary society will be examined, with a focus on the construction of a revolutionary continuum that links certain parts of Cuban history to the revolution of the 20th century. In a third step, we will look at the role of a set of

${ }^{1}$ Nina Jany is a graduate assistant and doctoral researcher in the Division of Sociology, Social Policy and Social Work, Department of Social Sciences: nina.jany@unifr.ch. 
social values, which have often been linked to the Cuban revolution by its supporters throughout different phases of the revolution. We will conclude with a short summary of the societal and economic developments during and after the special period - an expression used to describe the economic depression Cuba fell in after the collapse of the Soviet Union.

\section{The prelude of the Cuban revolution of 1959}

As noted above, the beginning of the Cuban revolution is most commonly dated to 1 January 1959. However, the historiography of the revolution embeds it into a larger context, notably that of former struggles for Cuban independence. The following summary of this context - or rather, of ex-post representations of this context - is by no means exhaustive and does not claim to be unmitigated. It deliberately focuses on the above-named topics, so as to enable a better understanding of the link between history, social values and the legitimation of an ongoing Cuban revolution.

Cuba had been under Spanish colonial rule for three and a half centuries (Spanish conquistador Diego Velázquez had arrived on the island in 1510) when the first calls for independence emerged in the second half of the 19th century. The first independence war (1868 1878), which was closely linked to anti-slavery movements, was lost against the colonial rulers. Despite the defeat, the war appeared to help the building of a Cuban identity among the people by uniting a population of different heritages and ranks (black and white people, slaves, plantation and landowners) against a common enemy (Hoffmann 2009: 33). ${ }^{2}$ Fostered by this new national consciousness, the strive for independence continued. Under the leadership of intellectual and writer José Martí (until his early death on the battlefields in 1895), as well as the military chiefs Antonio Maceo and Máximo Gómez, independence from Spain was finally achieved in 1898. The triumph, however, was short-lived: the end of Spanish colonial rule proved to be the beginning of US dominance over the country. The United States had both economic and geopolitical interests in the Cuban island, as it constitutes a key point of access to the Gulf of Mexico (Hoffmann 2009: 14). The US army entered the Cuban independence war - which then became the Spanish-American war ${ }^{3}$ - in its final stage in 1898 and occupied the island from 1898 to 1902 . Cuban representatives were excluded during the peace negotiations between Spain and the United States, which strengthened Cuban people's perception that their role in this war had been neglected (Hoffmann 2009; Wehrli 2009; Hartmann 2017). In 1902, the era of the so-called República Plattista began. The expression alludes to the Platt Amendment, a treaty containing several conditions set by Washington, which were amended to the constitution of the newly proclaimed Republic of Cuba. By means of this amendment, the United States ensured itself, among other things, "the right to intervene for the preserva-

\footnotetext{
${ }^{2}$ During Spanish colonial rule, black slaves (mostly from present day Angola, Congo, and Nigeria) were - legally and illegally - brought to the island (Wehrli 2009: 56). Since then, blacks and mulattos have constituted an important part of the Cuban population (Wehrli 2009: 56-58). A detailed description of the ethnic and racial composition of the Cuban people is provided by Gott (2004: 5-10).

${ }^{3}$ For further explanations on this war see, for example, Gott (2004).

${ }^{4}$ Incidentally, the US naval base near Guantanamo bay is a heritage of the Platt Amendment. In the first place, the agreement over the base was made for 99 years, but was later extended for an indefinite period of time (Hartmann 2017).
} 
tion of Cuban independence, the maintenance of a government adequate for the protection of life, property, and individual liberty" (quoted after Gott 2004: 327).

The Plattist Republic officially ended in 1934, when the Platt Amendment was terminated. Unofficially, however, Cuba remained under guardianship of the United States until the end of the 1950s: "US control of Cuba necessarily became less direct and obvious, and was now largely exercised through economic hegemony only" (Kapcia 2008: 19). With regard to internal developments, the first half of the century was characterised by political instability. The military dictatorship of "tropical Mussolini" (Gott 2004: 129) Gerardo Machado (1925-1933), the failed attempts of reform under president Ramón Grau San Martín (1933-1934; 19441948), and several other (ephemeral) governments defined the political landscape of what historians of the 1959 revolution later called the "pseudo-republic" (Miller 2003: 151; Gott 2004: 113). A man who exerted substantial influence on the politics of this era was Fulgencio Batista, acting president from 1940 to 1944 and - after his temporary retreat to the United states again from 1952 until 1958, following his coup d'état in 1952. Batista temporarily managed to stabilize the political system and enjoyed popular support owing to his progressive reform attempts (anchored in the constitution of 1940) and his strategic political alliances (Kapcia 2008: 17-19; Hoffmann 2009: 51). Cuba's economic situation was - at least temporarily - considered as relatively good among Latin American countries (Kapcia 2008: 7; Hartmann 2017: 397). This was partly due to sugar production, which had almost completely dominated the Cuban economy since the 17th century, and which was boosted when European and Asian sugar production collapsed during the world wars (Gott 2004: 144). Nonetheless, social inequality and poverty were far from being abolished; corruption, nepotism, and violence seemed to prevail under all of the numerous presidents that officially governed the island in the first half of the 20th century. As Krull and Kobayashi (2009: 164) describe, before 1959, "Cuba was known as the 'Bordello of the Caribbean' because its thriving tourist industry depended on prostitution, Mafia-run casinos, and a prosperous drug trade." This was particularly the case for the country's capital, Havana.

The growing dissatisfaction with the Batista regime enforced popular support for political opponents, among whom were the young lawyer Fidel Castro and his combatants. After their failed attack on the Moncada Barracks in Santiago de Cuba, Cuba's second largest military garrison at that time, on 26 July 1953, ${ }^{5}$ Fidel, his younger brother Raúl Castro, and the other survivors of the attack were imprisoned for two years. At their release in 1955, they went into Mexican exile, where they were joined by the Argentinian doctor Ernesto Che Guevara. The $26^{\text {th }}$ of July movement, as the rebels called themselves now, arrived in 1956 on the motor yacht Granma in the province of Oriente, where Batista troops attacked them. The survivors started a guerrilla battle in the east of Cuba. This time, with the growing support of the rural population, the rebellion was successful: when the guerrilla movement arrived in Havana on 1 January 1959, Batista fled the country and made way for the revolutionary government.

The history of colonial dependence from Spain, and even more the neo-colonial dependence from the United States, has played an important role for the popular support and the legitimation of the Cuban revolution over time. Up until today, Cuban narratives connect the

${ }^{5}$ For a detailed description of this event see, for example, Waters and Fernandez (2012). 
rebel's victory in 1959 to liberation, national sovereignty, the assertion of social values, and the hope to build a more equal society. In the following, we want to take a closer look at this connection.

\section{Historiography: The beginning of the revolution - constructing a revolutionary continuum}

Political revolutions rely on "order creating visions" that enforce the distance to the old order of society, and out of which emerge "symbolic legitimations of the new order" (Endruweit et al. 2014: 409, my translation) of the revolution. As often argued (e.g. Perez 1980, 1985; Gewecke 1990; Miller 2003; Gropas 2007; Waters and Fernandez 2012), historiography provides an important symbolic legitimation for the Cuban revolution of 1959. In Perez' (1980: 88) view, the construction of a "historical continuum" that links the past with the revolutionary present, has helped to create national solidarity and support for this revolution over time.

The historiography of the revolution of 1959 is mainly characterised by the heroes of the independence wars from Spanish colonial rule, of whom José Martí is probably the most important. Martí, considered as "the grandfather" (Gropas 2007: 541), "the apostle" or "the prophet" (e.g. Castro 2007: 44; Gewecke 1990: 77; Waters and Fernandez 2012: 129) of the revolution, stands for Cuban independence, anti-(US)-imperialism, pan-Americanism, and social justice (Hoffmann 2009: 34-35). Martí is still omnipresent in contemporary Cuba. His image is perpetuated in statues, murals and banknotes; his quotes and poems can be found in the 'mnemonic landscape' (Gropas 2007) all over the country, and his writings are an important element of school education (Wehrli 2009: 60). January 28th, Martís birthday, is one of the Cuban national commemoration days. Other heroes and myths of the 19th century independence wars, such as Carlos Manuel de Céspedes, Antonio Maceo, Máximo Gómez, and the image of the mambi $i^{6}$ as „archetype of the Cuban rebel“ (Wehrli 2009: 61, my translation) have also helped to legitimate and enforce the revolutionary project. In his famous defence $L a$ historía me absolverá, which he made in court after the attack on the Moncada Barracks, Fidel Castro (2007) linked these national heroes and myths to the causes of the rebellion. According to Wehrli (2009: 65, my translation), this speech allowed Castro to "position himself [within the national discourse]" and within "the genealogy of important characters". Miller (2003: 147) identifies the centrality of this defence of the revolutionary project history as "the key legitimating force behind the Cuban revolution."

After the triumph of the revolution in 1959, connecting the present to the struggles and heroes of the past continued to be an important pillar of revolutionary rhetoric. An early example of this is given by the celebration of cien años de lucha (hundred years of struggle) in 1968. The label of cien años de lucha - alluding to the beginning of the first independence war in 1868 - has been used as a theme for books, songs and stamps. An illustration of its official interpretation by the revolutionaries is provided by Fidel Castro's (1968) commemoration speech in Manzanillo in 1968, in which he depicts the commencements of the revolution in

\footnotetext{
${ }^{6}$ Presumably because of its 'African sound' (Hoffmann 2009: 38), the term mambi was originally used by the Spanish conquistadores as a derogatory designation for black rebels, first in the Dominican and then in the Cuban independence war (Gott 2004: 73). The warriors of the latter adopted this term, which was from then on used to denominate Cuban (guerilla) rebels fighting for the cause of independence.
} 
October 1868, when Carlos Manuel de Céspedes declared the independence of Cuba, and the mambises started the independence war. As described by Perez (1980: 86), with cien años de lucha, "[t]he themes of struggle and the continuity of the revolutionary process became fused [...] in a unifying historical construct".

In the first years of the revolution, the old order of Cuban society was overthrown completely. Soon after the revolutionary takeover, companies were nationalised, large landowners were expropriated and income was redistributed (Wehrli 2009: 67). The puritan Manuel Urrutia, who was appointed president from January to July 1959 (when Fidel Castro forced him to resign, Farber 2011: 13) made it his business to mark "a sharp break with Cuba's immediate past: brothels, gambling dens and the national lottery were to be closed down" (Gott 2004: 170). Revolutionary tribunals were established, in which actors and supporters of the Batista regime were sentenced to prison or death (Farber 2011: 35), without recourse to "formal procedures of a legal defence" (Miller 2003: 48). Many Cubans emigrated (mostly to the United States); an above-average number of them belonging to the white upper class of society (Wehrli 2009: 67). In 1961, Fidel Castro officially declared that the Cuban revolution was a socialist revolution (Kapcia 2008: 31 ). ${ }^{7}$ The societal, political, and economic shifts of this era were in line with the Soviet model of socialism: the whole economy was nationalised and a one-party government, exercising control over many aspects in public and private spheres, was established (Farber 2011: 2). However, "the Cuban version [of Soviet socialism] had its own national characteristics, as was also the case with China and Vietnam" (Farber 2011: 2), which is sometimes referred to as "tropical socialism" (e.g. Burchardt 1998; Hoffmann 2009; Wehrli 2009). The Cuban revolutionaries had not been formed within the Soviet regime, and were first and foremost characterised by their nationalist orientation (Gott 2004: 148-149, Hartmann 2017: 400). Yet, Fidel Castro successfully managed to connect the topics of socialism and Cuban nationalism, which, according to Gott, was "one of the keys to his political longevity" (Gott 2004: 149). One of the most important slogans of the revolutionary rhetoric, patria o muerte (fatherland or death), whose origins are said to be in the independence claims of 1868 (Hoffmann 2009: 87), was occasionally converted by Fidel Castro into socialismo o muerte (socialism or death). Fidel Castro's personality and rhetoric have played a distinct role for the course of the Cuban revolution, which cannot be treated in full length in this article. Yet, his importance for the historiography of the revolution is to be noted in this context. As indicated by the title attributed to him after his retirement, the historical leader of the Cuban revolution has, over the years, known how to keep his position within the genealogy of national heroes and to become the "superior appeal body, [...] the actual founder of the 'new era', who is identical with the revolution and its beginnings" (Gewecke 1990: 79, my translation).

\footnotetext{
${ }^{7}$ The discussion of whether the Cuban revolution was socialist in its roots, and which role was played by the interests and the opportunism of the revolutionary leaders, the United States and the Soviet Union is beyond the scope of this article. The interested reader is referred to Farber (2006); Kapcia (2008); Gott (2004).
} 


\section{The continuation of the revolution: Myths, revolutionary values and morality}

As described above, the Cuban revolution is often represented as the continuance of past struggles of national independence and social justice. From this perspective, the triumph of the revolution in 1959 is perceived as the hard-won fruit of past efforts made for a free and equal Cuban society. Out of this "intertwining of history and the Revolution" (Gropas 2007: 536), another important element that has served to consolidate the legitimation of the (continuing) revolution arises, namely the appeal on the moral duty of present generations to defend and to pursue the values and the achievements of this revolution. As mentioned before, revolutionary rhetoric links the heroes of the 19th century, but also and especially those of the 20th century - Fidel Castro and Che Guevara, as well as a whole generation of revolutionaries who helped to build the new order of society - to values such as social justice and equality, morality, voluntary work and social property.

In Gewecke's (1990) view, myths of success and myths of defence ${ }^{8}$ are important for the course of the Cuban revolution and its legitimacy within the Cuban population. In her opinion, both types of myth provide motivation, "specifically as an appeal to identify with the revolution by means of its achievements and - also in the sense of 'compensation myths' - to readily accept sacrifices and shortcomings" (Gewecke 1990: 80-81, my translation). What could be described as a Cuban myth of defence has in part been explained in the previous section, namely the threat of external invasion associated with Cuba's history of colonial and neo-colonial dependence. According to Gropas (2007: 535)

[t]he defence of la patria from external aggression (in its multitude and varied forms) is thus translated into an almost sacred historical 'obligation' to the Cubans who, throughout the nation's history, have died in defence of la patria's freedom. This historical point is felt even by the Revolution's fiercest Cuban critics living on the island.

Moreover, myths of defence may provide legitimation for an enforced state control and an appeal to vigilance among the population (Gewecke 1990: 80), legitimating institutions such as the Comités de Defensa de la Revolución (neighbourhood committees in defence of the revolution). Originally created in order to identify potential collaborators of an expected US invasion in September 1960 (Kapcia 2008: 67), these committees have ever since played an important role in the surveillance and the overall organisation of the society (Wehrli 2009: 7578). The relationship between Cuba and the United States - which have their own myths and emotionally charged rhetoric when it comes to Cuba - is a complex and controversial topic that cannot be extensively addressed here. Yet, we can state that this relationship has influenced the course of the Cuban revolution, also regarding its emphasis on values and morality. The closing down of brothels and casinos as one of the first acts of the revolutionary government may be interpreted as an illustration of the message this new government wanted to

\footnotetext{
${ }^{8}$ According to Gewecke's (1990: 74-75) definition, in this context, the term myth does not describe fictional, untruthful, or irrational relations. It is rather to be understood as a rationale to represent contexts as absolute truths.
} 
send out from the start, notably "that the nation no longer prepared to play the prostitute to the desires of US imperialists and their local lackeys" (Miller 2003: 147).

Regarding the myths of success of the Cuban revolution, we can draw on what is often referred to as the achievements of the revolution, most notably the Cuban educational- and health care systems (Hoffmann 2009; Wehrli 2009, Farber 2011). The starting point of the former may be located in the literacy campaign in 1961, during which more than 700,000 adults were alphabetised by around 250,000 volunteers in less than a year (Gewecke 1990: 80). Especially for the approximately 100,000 young brigadista volunteers among them, the campaign had as much of a life-changing impact as on the alphabetised population (Kapcia 2008: 47). Organised in a military style, the campaign permitted these teenagers, who had not taken part in the guerrilla war of the 1950s, to consider themselves as revolutionaries, exercising an important role within the beginning phase of the revolutionary process (Gott 2004: 189, Kapcia 2008: 47-48). In Miller's view (2003: 150), the campaign was a "major vehicle for inculcating a sense of history" in this first phase of the revolution. According to Kapcia (2008: 47), "[d]esigned with political as much as social objectives - to integrate the neglected rural population into the new political process - it was one of the Revolution's most ambitious and most successful reforms." The campaign is often perceived as the prime example of the societal efforts made by the revolutionary generation following the role model of Che Guevara's (1987) ideal of a new man, who works selflessly for the common good. Along with other campaigns and projects based on voluntary labour (see, for example Kapcia 2008: 66), as well as the social and economic improvements during the first two decades of the revolution (such as significantly reducing malnutrition, unemployment and massive poverty, Burchardt 1998: 25; or advances in gender equality and the overall situation of many Cuban women, Krull and Kobayashi 2009: 165), this campaign has ever since played an important role for the legitimation of the (ongoing) Cuban revolution.

\section{(How) does the Cuban revolution survive?}

The island's economy slowed during the 1980s and - with the end of the Soviet Union, Cuba's most important trading partner at that time - fell into a deep economic crisis in the early 1990s, which was worsened by an enforced US-embargo (by means of the Torricelli law in 1992 and the Helms-Burton-law in 1996). The crisis was characterised by economic scarcity, inflation, stagnating wages, unemployment, and growing activities on the black market. In 1990, Fidel Castro proclaimed the special period in times of peace, "an emergency-war economy to withstand the coming collapse" (Kapcia 2008: 43). The US-Dollar was legalised again in the country, foreign investment and self-employment were partly reintroduced. The growing tourist sector, informal and illegal activities, as well as remittances (mostly from Cuban expatriates in the United States) helped many Cubans to make ends meet, but also contributed to growing inequalities within society. It is often asked how the revolutionary government and its leaders could survive the collapse of the Soviet Union and the severe economic depression that followed for the Cuban island. Given the range of factors in play, there is no single answer to this question. The easing of economic restrictions, as well as the - officially permitted mass exodus of about 35,000 to 40,000 Cubans (also known as the balsero-crisis) following the 
habanazo, a massive protest in Havana in August 1994, have certainly contributed to its survival (Wehrli 2009: 89-90). Moreover, regarding the symbolic dimension of the Cuban revolution perceived as an ongoing process, the special period may have served as a purifying experience, as it allowed for open criticism of Soviet socialism, while emphasizing the "Revolution's Cubanness", as well as "the Revolution's socialist set of values, including free health care, education, and social equality" (Gropas 2007: 538).

Indeed, up until today, many Cubans living on the island - even critics of the government (Gropas 2007: 535) - seem to associate the Cuban revolution with the above-described principles and values, such as social equality, sovereignty, anti-imperialism, and the work for the common good. ${ }^{9}$ The historiography of the Cuban revolution and its emphasis on such Cuban values and morality thus appears to play an important part in ensuring continuous support for the political projects of the revolutionary government. Certainly, the transition from Fidel Castro to his younger brother Raúl in the year 2008 led to important political and economic changes (e.g. Hoffmann 2016). These include, for example, the frequently mentioned changing policy towards the private sector, and especially the wave of liberalisations of cuentapropismo, that is, of small self-employed businesses, which are vital to the Cuban economy (e.g. Ritter and Henken 2015). However, as pointed out by Farber (2011:2),

the Cuban regime has for more than twenty years managed to survive the fall of the Soviet Union - its principal patron and senior ally - and the East European Soviet bloc. In the company of North Korea, it continued to exist during that period without a major turn toward capitalism, as has been the case with China and Vietnam.

Indeed, looking at the example of self-employment, the prediction of a turn from a state- to a market-led society appears to be a risky undertaking. In 2017, the Cuban government announced a rearrangement of the private sector, including a halt in the issuing of licences for several self-employed activities (Puig Meneses 2017). There is reason to believe that the announced resignation of Raúl Castro and the change of government in April 2018 will not lead to abrupt changes in the actual political course, so that the continuation of the revolutionary process may be ensured. Yet, with the substantial changes that this process has undergone since the beginning of the 21st century, the question whether and to which extent the revolutionary values discussed above will survive in revolutionary rhetoric and as a pillar for the revolution's popular support, remains to be seen.

\section{References}

Burchardt, Hans-Jürgen (1998). Deberían leer en Cuba a Bourdieu? Socialismo, estructura social y capital social. Análysis Político 34(2), 24-43.

Castro, Fidel (1968). Discurso pronunciado por el comandante Fidel Castro Ruz en el resumen de la velada conmemorativa de los cien años de lucha en Manzanillo, Oriente, el 10 de octubre de 1968. Website. Retrieved January 3, 2018, from http://www.cuba.cu/gobierno/discursos/1968/esp/ f101068e.html

${ }^{9}$ While there certainly are significant differences in this association with regards to different generations (see, for example, Krull and Kobayashi 2009). 
Castro, Fidel (2007). La historía me absolverá (5th edition). Editorial de Ciencias Sociales: La Habana.

Endruweit, Günter, Gisela Trommsdorff and Nicole Burzan (ed.) (2014). Wörterbuch der Soziologie (3rd edition). Konstanz: UVK.

Farber, Samuel (2006). The Origins of the Cuban Revolution Reconsidered. Chapel Hill: University of North Carolina Press.

Farber, Samuel (2011). Cuba since the Revolution of 1959. A Critical Assessment. Chicago: Haymarket Books.

Gewecke, Frauke (1990). Mythen als Begründungs- und Beglaubigungsrede: das Beispiel der Kubanischen Revolution. Iberoamericana, 14(2), 74-95.

Gott, Richard (2004). Cuba: A New History. New Haven: Yale University Press.

Gropas, Maria (2007). The Repatriotization of Revolutionary Ideology and Mnemonic Landscape in Present Day Havana. Current Anthropology, 48(4), 531-549.

Grosser, Florian (2013). Theorien der Revolution zur Einführung. Hamburg: Junius.

Guevara, Ernesto 'Che' (1987). El socialismo y el hombre nuevo (7th edition). México, D.F.: Siglo XXI Editores.

Hartmann, Jürgen (2017). Die politischen Systeme Lateinamerikas. Ein Überblick. Wiesbaden: Springer Fachmedien.

Hoffmann, Bert (2009). Kuba (3rd edition revised). München: C.H. Beck.

Hoffmann, Bert (2016). Bureaucratic Socialism in Reform Mode: The Changing Politics of Cuba's post-Fidel Era, Third World Quarterly, 37(9), 1730-1744.

Kapcia, Antoni (2008). Cuba in Revolution: A History Since the Fifties. London: Reaktion Books.

Krull, Catherine and Audrey Kobayashi (2009). Shared Memories, Common Vision: Generations, Sociopolitical Consciousness and Resistance among Cuban Women. Sociological Inquiry, 79(2), 163-89.

Miller, Nicola (2003). The Absolution of History: Uses of the Past in Castro's Cuba. Journal of Contemporary History, 38(2), 147-162.

Pérez, Louis A., Jr. (1980). In the service of the Revolution: Two decades of Cuban historiography 1959-1979. The Hispanic American Historical Review 60(1), 79-89.

Pérez, Louis A., Jr. (1985). Toward a new future, from a new past: The enterprise of history in Socialist Cuba. Cuban Studies 15(1), 1-13.

Puig Meneses, Yaima (2017). Trabajo por cuenta propia. Por la ruta de la actualización. Website. Retrieved January 8, 2018, from http://www.granma.cu/cuba/2017-08-01/por-la-ruta-de-laactualizacion-01-08-2017-00-08-07

Ritter, Archibald R.M. and Ted A. Henken (2015). Entrepreneurial Cuba. The Changing Policy Landscape. Colorado: FirstForumPress.

Scott, John and Gordon Marshall (ed.) (2014). A Dictionary of Sociology (4th edition revised). Oxford: Oxford University Press. 
Waters, Anita and Luci Fernandez (2012). Representing the Revolution: Public History and The Moncada Barracks in Santiago De Cuba. Canadian Journal of Latin American and Caribbean Studies/ Revue canadienne des études latino-américaines et caraïbes, 37/73, 125-154.

Wehrli, Angelica (2009). Viva la creatividad. Strategien zur Existenzsicherung in Zeiten des sozioökonomischen Wandels auf Kuba. Zürich: LIT Verlag. 